УДК 343.132

DOI https:// doi.org/10.32837/yuv.v0i3.1944

М. Никоненко,

кандидат юридичних наук, доцент,

професор кафедри кримінального процесу

Національної академії внутрішніх справ

\title{
ДОПИТ МАЛОЛІТНЬОЇ АБО НЕПОВНОЛІТНЬОЇ ОСОБИ НА СТАДІЇ ДОСУДОВОГО РОЗСЛІДУВАННЯ
}

Процес доказування у кримінальному провадженні являє собою сукупність складових елементів, які логічно i збалансовано створюють єдину та нероздільну систему дій і рішень уповноважених державних органів і посадових осіб, що дає змогу забезпечити виконання завдань кримінального провадження, передбачених ст. 2 Кримінального процесуального кодексу України (далі - КПК Україн) [1]. Кожен термін у врегульованих законом завданнях кримінального провадження несе досить виважений i водночас дієвий зміст i фактично $€$ свого роду дороговказом для вибору засобів і способів діяльності кожного з учасників кримінального провадження. Особливо це стосується тих учасників, які представляють сторону кримінального провадження з боку обвинувачення. Ними, згідно 3 п. 19 ч. 1 ст. 3 КПК України, є слідчий, дізнавач, керівник органу досудового розслідування, керівник органу дізнання, прокурор.

I перед цими учасниками кримінального провадження, виходячи із його завдань, стоїть непросте завдання: виконуючи свої функціональні обов'язки, $з$ одного боку, необхідно забезпечити охорону прав, свобод та законних інтересів усіх без винятку інших учасників кримінального провадження, а $з$ іншого - забезпечити швидке, повне та неупереджене розслідування і судовий розгляд.

При цьому підвищені вимоги до таких учасників кримінального прова- дження ставляться в тому разі, якщо у сферу дії кримінальних процесуальних правовідносин потрапляють особи до досягнення ними повноліття. Тобто особи, які, згідно з ч. 3 ст. 484 КПК України, не досягли вісімнадцятирічного віку. Визначаючи порядок здійснення кримінального провадження щодо названої категорії осіб, законодавець у ч. 1 ст. 484 КПК України підкреслює, що порядок кримінального провадження щодо неповнолітніх визначається загальними правилами КПК України з урахуванням особливостей, передбачених главою $38 \mathrm{KПK}$ України, яка має назву «Кримінальне провадження щодо неповнолітніх».

I тут відразу хотілося б звернути увагу на один, як уявляється, досить важливий момент. Так, згідно з ч. 3 ст. 484 КПК України, положення параграфа першого глави 38 КПК України, що має назву «Загальні правила кримінального провадження щодо неповнолітніх», застосовуються, про що вище вже зазначалося, у кримінальному провадженні щодо кримінальних правопорушень, учинених особами, які не досягли вісімнадцятирічного віку.

Уявляється, що для того, щоб розставити всі крапки над «і», варто було б виступити 3 ініціативою про доповнення названого положення, де після слів «...які не досягли вісімнадцятирічного віку» зазначити «на момент учинення кримінального правопорушення». Тоді буде чітко зрозуміло, що положення названого 
параграфу будуть застосовуватись як у кримінальних провадженнях про кримінальні правопорушення, вчинені особами, які не досягли вісімнадцятирічного віку, як на момент вчинення кримінального правопорушення, так i на період здійснення досудового розслідування чи судового розгляду, так і у кримінальних провадженнях про кримінальні правопорушення, вчинені особами до досягнення ними вісімнадцятирічного віку, але які на період здійснення досудового розслідування чи судового розгляду досягли вісімнадцятирічного віку. Запропоноване доповнення послужить додатковою гарантією охорони прав, свобод і законних інтересів названої категорії осіб.

А щодо особливостей, передбачених вищеназваною главою $38 \mathrm{KПK}$ України, то вони стосуються, з огляду на зміст ч. 2 ст. 384 КПК України, саме підвищення рівня гарантій прав, свобод і законних інтересів названої категорії осіб. Саме так слід тлумачити сформоване у ч. 2 ст. 384 КПК України положення стосовно того, що під час кримінального провадження щодо неповнолітнього, у тому числі під час провадження щодо застосування примусових заходів виховного характеру, слідчий, прокурор, слідчий суддя, суд та всі інші особи, що беруть у ньому участь, зобов'язані здійснювати процесуальні дії в порядку, що найменше порушує звичайний уклад життя неповнолітнього та відповідає його віковим та психологічним особливостям, роз'яснювати суть процесуальних дій, рішень та їх значення, вислуховувати його аргументи під час прийняття процесуальних рішень та вживати всіх інших заходів, спрямованих на уникнення негативного впливу на неповнолітнього.

Заради забезпечення можливості дотримання вимог законодавства саме у цьому форматі законодавець створив додаткові важелі щодо визначення порядку проведення досудового розслідування, зазна- чивши в ч. 1 ст. 494 КПК України, що якщо неповнолітній підозрюється у вчиненні кримінального правопорушення разом із повнолітнім, повинна бути з'ясована можливість виділення в окреме цього кримінального провадження щодо неповнолітнього під час досудового розслідування.

3 урахуванням практики застосування кримінального процесуального законодавства можливо виділити значну кількість проблем, що стосуються саме здійснення кримінального провадження щодо неповнолітніх. Проте, орієнтуючись на запропоновану тему й ураховуючи рекомендований обсяг матеріалу, що подається, акцент уваги спрямовуємо на досить актуальний блок проблем, пов'язаний із допитом малолітньої або неповнолітньої особи на стадії досудового розслідування 3 метою дослідити стан законодавства, яким урегульовується порядок проведення такого допиту, практику його застосування, визначити шляхи вдосконалення чинного законодавства та практики його застосування i намітити перспективи подальших досліджень у цьому напрямі.

Розпочнемо розгляд названого блоку проблем саме 3 визначення місця проведення допиту малолітньої або неповнолітньої особи.

Акцентуючи увагу на такому питанні, слід зазначити, що, згідно з ч. 1 ст. 224 КПК України, допит проводиться за місцем проведення досудового розслідування або в іншому місці за погодженням з особою, яку мають намір допитати. Щоб зрозуміти логіку законодавця стосовно загального правила визначення місця проведення досудового розслідування, необхідно звернутися до ч. 1 ст. 218 КПК Украіни, де визначено, що досудове розслідування здійснюється слідчим того органу досудового розслідування, під юрисдикцією якого знаходиться місце вчинення кримінального правопорушення. Тобто саме місце розташування органу досудового 
розслідування визначається як місце проведення досудового розслідування.

Що ж стосується визначення іншого місця для проведення допиту, то у разі допиту малолітньої або неповнолітньої особи, уявляється, не буде відступом від вимог кримінального процесуального законодавства, якщо такий допит буде проведений у спеціально обладнаному приміщенні. I тут доречно було б згадати про так звану методику під назвою «Зелена кімната», яка використовувалася під час допиту, як правило, малолітніх осіб. У літературі знаходимо визначення такого поняття. Так, «Зелена кімната» - спеціально організована система заходів, що має на меті забезпечити законність, гуманність та ефективність кожного рішення щодо дитини, яка потрапила у конфлікт із законом чи перебуває у контакті із законом [2, с. 4]. Але законодавчого закріплення існування методики під назвою «Зелена кімната» ми на разі не спостерігаємо.

Проте якщо заглянути в історію існування методики під такою назвою, то можливо знайти у чинній до 2017 р. відомчій Інструкції 3 організації роботи підрозділів кримінальної міліції у справах дітей [3], а саме в розділі восьмому, що мав назву «Організація надання правової та психологічної допомоги дітям, які є потерпілими в кримінальному провадженні чи стали свідками злочину», детальне роз'яснення про застосування такої методики.

I тут цікавими є три положення. Перше - це те, що за окремим дорученням слідчого чи прокурора допит дитини проводив працівник підрозділу кримінальної міліції у справах дітей. Друге - це те, що проведення опитування дитини, яка є потерпілою або свідком у кримінальному провадженні, здійснюється у спеціально обладнаному приміщенні чи облаштованому для цих цілей приміщенні із застосуванням методики «Зелена кімната». I третій момент, про який йшлося у названій Інструкції, стосується вікових категорій дітей. Зокрема, там зазначалося про те, що методика «Зелена кімната» застосовується до дітей віком від 4 до 14 років, а на розсуд слідчого чи суду - й у віці від 14 до 16 років, які потерпіли внаслідок учинення злочинів проти статевої свободи і недоторканності, інших злочинів насильницького характеру або стали свідками таких злочинів. Слід відзначити, що це досить цікавий підхід до організації надання правової та психологічної допомоги дітям.

До речі, відомча Інструкція з організації роботи підрозділів ювенальної превенції Національної поліції України, що $є$ чинною, застосування такої і інших подібних методик не передбачає [4].

B описаній вище методиці, як було сказано, є один дуже цікавий момент - застосування методики до дітей залежно від вікових категорій.

До речі, на ці проблеми в літературі зверталася увага. Так, К.С. Тищенко 3 посиланням на науково-практичний посібник із питань розслідування злочинів підкреслює, що кабінет слідчого не буде вдало вибраним місцем допиту неповнолітніх молодших вікових груп. Як альтернативу можна використовувати спеціально обладнаний кабінет психолога, куди слідчий може викликати допитуваного та інших учасників кримінального провадження, яким законом надано право бути присутнім на такому допиті. Допит неповнолітніх старших вікових груп, навпаки, доцільно проводити в кабінеті слідчого [5, с. 646].

А.В. Даниленко і О.О. Кочура, звертаючи увагу на вибір місця проведення допиту малолітніх осіб, також зазначили, що потерпілих дошкільного віку (від трьох до шести років) слід допитувати за місцем їх проживання, адже знайома для них обстановка допоможе слідчому швидше встановити психологічний контакт із неповнолітнім [6, с. 45].

При цьому слід звертати увагу на те, що якщо така особа виступає у кримінальному провадженні 
як потерпіла, то до участі у допиті, згідно з ч. 1 ст. 59 КПК України, разом із нею залучається ї законний представник.

А що стосується охорони прав, свобод i законних інтересів неповнолітньої особи під час взаємодії із законним представником, то законодавець із цією метою передбачив певні гарантії. Так, згідно з ч. 4 ст. 44 КПК України, у разі якщо дії чи інтереси законного представника суперечать інтересам особи, яку він представляє, за рішенням слідчого, прокурора, слідчого судді, суду такий законний представник замінюється іншим.

Звертає на себе увагу також питання виклику на допит неповнолітньої особи. Так, наприклад, згідно 3 ч. 1 ст. 489 КПК України, неповнолітній підозрюваний чи обвинувачений повідомляється або викликається слідчим, прокурором, слідчим суддею чи судом через його батьків або інших законних представників. Інший порядок допускається лише в разі, якщо це зумовлюється обставинами, встановленими під час кримінального провадження. I саме в продовження останнього положення, що стосується іншого порядку виклику, хотілося б зазначити, що в подальшому про таке повідомлення чи виклик в обов'язковому порядку невідкладно необхідно поставити до відома батьків або інших законних представників неповнолітнього. Законодавець на разі такого не вимагає, проте, уявляється, саме таке положення сприяло б підвищенню рівня захищеності малолітньої або неповнолітньої особи.

Тепер щодо проблем, пов'язаних з організацією допиту названої категорії осіб. Тут необхідно дати відповідь на питання, які виникають, як правило, у кожного, хто до такого допиту причетний.

Взяти, наприклад, питання щодо часу проведення допиту. Так, згідно 3 ч. 2 ст. 226 КПК України, допит малолітньої або неповнолітньої особи не може продовжуватися без перерви понад одну годину, а загалом - понад дві години на день. До речі, із цього приводу в літературі зазначається, що тривалість допиту не може бути єдиною для всіх дітей. Вона визначається з урахуванням віку та індивідуальних особливостей дитини [6, с. 49].

У продовження розгляду цієї проблеми Н.В. Павлюк виступила 3 пропозицією про визначення в законі конкретного проміжку часу на проведення допиту малолітньої або неповнолітньої особи залежно від вікових категорій таких осіб [7, с. 194-195]. Уявляється, що таке питання потребує додаткового дослідження.

Проте слід пам'ятати, що і тривалість перерви законом не визначено. I це не прогалина в законі. Зрозуміло, що перерва повинна бути обов'язково, але їі тривалість залежить від багатьох чинників, тому визначати конкретний проміжок часу для перерви було б рішенням помилковим. Варто лише в порядку рекомендації зазначити щодо мінімального проміжку часу для перерви при допиті. Так, уявляється, що відведений для перерви час повинен бути об'єктивно достатнім для досягнення мети перерви.

Мабуть, не викликає потреби детально висвітлювати питання щодо кола осіб, які можуть у тій чи іншій ролі виступали під час допиту малолітньої чи неповнолітньої особи. Питання кола таких осіб законом чітко врегульовані. Проте на практиці виникає питання щодо того, хто безпосередньо знаходиться біля дитини під час допиту.

У ч. 1 ст. 226 КПК України законодавцем конкретно зазначено, що допит малолітньої або неповнолітньої особи проводиться у присутності законного представника, педагога або психолога, а за необхідності - лікаря. I тут акцент уваги, уявляється, слід спрямувати саме на формулювання «y $n p u$ сутності» (виділено мною. - Н.М.). Значить, конкретний виконавець слідчої дії все-таки є слідчий. Він і знаходиться біля особи, яка допитується. 
Як на аргументи у підтвердження цьому слід посилатися на два положення законодавства. Перше положення закріплено в ч. 1 ст. 104 КПК України, згідно з яким у випадках, передбачених КПК України, хід i результати проведення процесуальної дії фіксуються у протоколі. А друге положення закріплено у ч. 1 ст. 106 КПК України, згідного з яким протокол під час досудового розслідування складається слідчим або прокурором, які проводять відповідну процесуальну дію, під час іiі проведення або безпосередньо після i закінчення.

Отже, згідно з ч. 2 ст. 484 КПК України, допит малолітньої або неповнолітньої особи проводить слідчий, спеціально уповноважений керівником органу досудового розслідування на здійснення досудових розслідувань щодо неповнолітніх. I саме цей слідчий складає протокол під час допиту неповнолітньої особи або безпосередньо після закінчення такого допиту. Але це не заважає законному представнику, педагогу або психологу, а також лікарю, у присутності яких проводиться допит, за дозволом, згідно з ч. 2 ст. 227 КПК України, ставити уточнюючі запитання малолітній або неповнолітній особі, а також, згідно 3 ч. 2 ст. 226 КПК України, заперечувати проти запитань та ставити запитання.

Проте, якщо повернутися до положень вищеназваної ч. 2 ст. 484 КПК України стосовно проведення досудового розслідування слідчим, спеціально уповноваженим керівником органу досудового розслідування на здійснення досудових розслідувань щодо неповнолітніх, то вбачається одна проблема, на яку звернула увагу Ю. Гошовська. Йдеться про ситуацію, коли слідчі, керуючись вимогами ст. 40 КПК України, направляють доручення оперативним підрозділам на допит свідків у кримінальному провадженні, то в число осіб, що підлягають допиту, потрапляють і неповнолітні, а це суперечить вимогам ст. 484 КПК України [8, с. 132]. Дійсно, слід зазначити, що проблема у цьому вбачається. Якщо виходити 3 того, що досудове розслідування складається із сукупності окремих слідчих дій і прийнятих рішень, то описана ситуація виглядає як порушення чинного законодавства.

Варто звернути увагу ще на кілька проблемних питань, пов'язаних із допитом малолітньої або неповнолітньої особи. Одне 3 таких питань - можливість візуального контакту такої особи з підозрюваним чи обвинуваченим, а інше - це питання щодо вибору законного представника малолітньої або неповнолітньої особи.

Слід відзначити, що в літературі досить справедливо зазначається про те, що «дитина не повинна в жодному разі зустрічатися зі звинуваченим у вчиненні злочину, що розслідується. Якщо необхідно провести впізнання підозрюваних, це може бути зроблене тільки через скло позавізуального спостереження. Якщо дитина побачить виконавця злочину безпосередньо, шанси отримання достовірної інформації значно зменшаться» [9, c. 14-15].

Більше того, законодавець із метою подальшої охорони прав, свобод і законних інтересів малолітнього або неповнолітнього свідка чи потерпілого створив додаткові гарантії, зазначивши у ч. 9 ст. 224 КПК України про те, що у кримінальних провадженнях щодо злочинів проти статевої свободи та статевої недоторканості особи, а також щодо злочинів, учинених із застосуванням насильства або погрозою його застосування, одночасний допит двох чи більше вже допитаних осіб для з'ясування причин розбіжностей в їхніх показаннях не може бути проведений за участю малолітнього або неповнолітнього свідка чи потерпілого разом із підозрюваним.

A що стосується питання про участь у допиті малолітньої або неповнолітньої особи законного представ- 
ника такої особи, то це також інколи може викликати певні ускладнення. Із цього приводу в літературі зазначається, що «...у ситуації, коли дитина саме в родині від батьків або родичів потерпає від насильства, система ювенальної юстиції має допомогти вчасно захисти права дитини» [9, с. 22]. Законодавець не обійшов увагою це питання і створив гарантії охорони прав, свобод і законних інтересів малолітньої або неповнолітньої особи в питаннях вибору законного представника. Так, згідно з ч. 3 ст. 227 КПК України, у виняткових випадках, коли участь законного представника може завдати шкоди інтересам малолітнього або неповнолітнього свідка, потерпілого, слідчий, прокурор за клопотанням малолітнього або неповнолітнього чи 3 власної ініціативи має право обмежити участь законного представника у виконанні окремих слідчих (розшукових) дій або усунути його від участі у кримінальному провадженні та залучити замість нього іншого законного представника. Проте на практиці в таких питаннях, як правило, проблем не виникає. Проблеми виникають в інших питаннях, на які акцентувалася увага у даному дослідженні.

Отже, підводячи підсумок, слід зазначити, що кримінальне процесуальне законодавство, яким урегульовується порядок проведення допиту малолітньої або неповнолітньої особи, потребує вдосконалення. Особливо це стосується чіткого врегулювання в законі питання виклику такої особи на допит, питання часу проведення допиту залежно від вікових категорій неповнолітніх, а також питання допиту неповнолітніх саме слідчими, спеціально уповноваженими на здійснення досудового розслідування щодо неповнолітніх.

У статті досліджено нацуінальне законодавство щодо врегулювання проблем допиту малолітньої чи неповнолітньої особи на стадії досудового розслідування. Акиен- товано увагу на тому, що перед учасниками кримінального провадження, які представляють сторону кримінального провадження з боку обвинувачення (ними, згідно $з$ п. 19 ч. $1 \mathrm{~cm} .3$ КПК України, як представники державних органів є слідчии, дізнавач, керівник органу досудового розслідування, керівник органу дізнання, прокурор), виходячи із його завдань, стоїть непросте завдання: виконуючи свої функиіональні обов'язки, з одного боку, необхідно забезпечити охорону прав, свобод та законних інтересів усіх без винятку учасників кримінального провадження, а з іншого - забезпечити швидке, повне та неупереджене розслідування $i$ судовий розгляд. При иьому підвищені вимоги до учасників кримінального провадження ставляться у тому разі, якщо у сферу діi кримінальних процесуальних правовідносин потрапляють особи до досягнення ними повноліття. Автор виступив з ініціативою про вдосконалення положення ч. 3 ст. 484 КПК України, де запропонував після слів «...у кримінальному провадженні щзодо кримінальних правопорушень, учинених особами, які не досягли вісімнадиятирічного віку» доповнити словами «...на момент учинення кримінального правопорушення», шо послужить додатковою гарантією охорони прав $і$ законних інтересів осіб, які вчинили кримінальне правопорушення до досягнення ними вісімнадиятирічного віку, але на період здійснення досудового розслідування чи судового розгляду досягли вісімнадияятирічного віку. Автором висловлено рекомендаиї стосовно того, що під час допиту неповнолітньої особи відведений для перерви час повинен бути об'єктивно достатнім для досягнення мети перерви. Акиентовано увагу на тому, що допит малолітньої або неповнолітньої особи проводиться 
у присутності законного представника, педагога або психолога, а за необхідності - лікаря, але проводить ию слідчу дію слідчий, який спеціально уповноважений керівником органу досудового розслідування на здійснення досудових розслідувань щодо неповнолітніх. I саме ией слідчий складає протокол під час donumy неповнолітньої особи або безпосередньо після закінчення такого допиту. Звернено увагу на низку проблемних питань, які потребують вирішення. Зокрема, йдеться про визначення різного проміжку часу для допиту окремих категорій малолітніх $i$ неповнолітніх осіб, про вирішення питання про дотримання законодавства під час здійснення допиту названої категорії осіб.

Ключові слова: малолітня або неповнолітня особа, слідчий, допит, місце проведення допиту, час допиту.

Nikonenko $M$. Interrogation of a minor or juvenile at the stage of pre-trial investigation

The article examines national legislation on the settlement of problems of interrogation of a minor or juvenile at the stage of pre-trial investigation. Emphasis is placed on the fact that before the participants in the criminal proceedings, who represent the criminal proceedings by the prosecution (they, according to paragraph 19 of Part 1 of Article 3 of the CPC of Ukraine, as representatives of state bodies, are the investigator, inquirysseur, head of pre-trial investigation, head of the inquiry body, prosecutor), based on its tasks, is not an easy task: performing their functional duties, on the one hand it is necessary to protect the rights, freedoms and legitimate interests of all without exception participants in criminal proceedings, and on the other - ensure rapid, full and impartial investigation and trial. Thus the raisedncreased requirements to participants of criminal proceedings are put in the event that in the sphere of action of criminal procedural legal relations there are persons before reaching their adulthood. The author took the initiative to improve the provisions of Part 3 of Art. 484 of the CPC of Ukraine, where he proposed after the words «... in criminal proceedings for criminal offenses committed by persons under eighteen years of age», to add the words «... at the time of the criminal offense», which will serve as an additional guarantee of protection of rights and legitimate interests of persons who have committed a criminal offense before they reached the age of eighteen, but for the period of pre-trial investigation or trial, reached the age of eighteen. The author recommends that during the interrogation of a minor, the time allotted for a break should be objectively sufficient to achieve the goal of the break. It is emphasized that the interrogation of a minor is conducted in the presence of a legal representative, teacher or psychologist, and if necessary - a doctor, but this investigative action is carried out by an investigator who is specially authorized by the head of the pre-trial investigation body to conduct pre-trial investigations into minors. And it is this investigator who draws up the report during the interrogation of a minor or immediately after the end of such interrogation. Attention is paid to a number of problematic issues that need to be addressed. In particular, it is a question of definition of various interval of time for interrogation of separate categories of minors, about the decision of a question of observance of the legislation at carrying out interrogation of the specified category of persons.

Key words: minor or juvenile, investigator, interrogation, place of interrogation, time of interrogation.

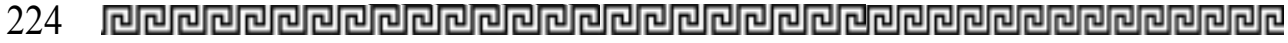




\section{Література}

1. Кримінальний проиесуальний кодекс України від 13 квітня 2012 року № 4651VI. База даних «Законодавство Українu». URL: https: / / zakon.rada.gov.ua/ laws/show/4651-17 (дата звернення: 10.07.2020).

2. Кравченко І.С., Кононець В.П. Застосування методики «Зелена кімната» в діяльності Національної полімії : методичні рекомендації для проведення занять зі слухачами на базі тренінгового центру «Зелена кімната» Дніпропетровського державного університету внутрішніх справ. Дніпро : ДДУВС, 2018. $48 \mathrm{c}$

3. Про затвердження Інструкиї з організаціі роботи підрозділів кримінальної міліиї в справах дітей : Наказ МВС України від 19.12.2012 № 1176. База даних «Законодавство України». URL: https: / / zakon.rada.gov.ua / laws / show / z0121-13 (дата звернення: 11.07.2020).

4. Про затвердження Інструкції з організації роботи підрозділів ювенальної превенції Національної поліиії України : Наказ МВС України від
19.12.2017 № 1044. База даних «ЗаконодавствоУкраїни». URL: https:// zakon.rada.gov.ua/laws/show/z0686-18 (дата звернення: 11.07.2020).

5. Тищенко К.С. Особливості проведення допиту малолітніх та неповнолітніх на стадіï досудового розслідування. Молодий вчений. 2018. № 5(57). С. 645-648.

6. Даниленко А.В., Кочура О.О. Особливості проведення допиту за участю неповнолітнього потерпілого під час досудового розслідування. Журнал східноєвропейського права. 2014. № 10. С. 44-50.

7. Павлюк Н.В. Проблеми підготовки до допиту неповнолітніх під час досудового розслідування. Питання боротьби зі злочинністю. 2013. № 25. С. 186-196.

8. Гошовська Ю. Допит неповнолітніх у кримінальному провадженні на стадіі досудового розслідування. Национальный юридический журнал: теория и практика. 2016. Апрель. С. 130-133.

9. «Зелені кімнати»: рекомендації до обладнання / Н.П. Бочкор та ін. Київ : Агентство «Україна», 2012. 28 c. 